\title{
Forecasted coral reef decline in marine biodiversity hotspots under climate change
}

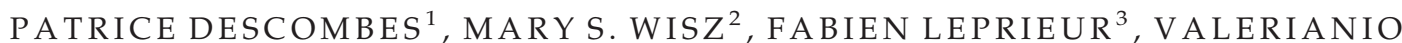 \\ PARRAVICINI ${ }^{4,5}$, CHRISTIAN HEINE ${ }^{6,7}$, STEFFEN M. OLSEN ${ }^{8}$, DIDIER SWINGEDOUW ${ }^{9}$, \\ MICHEL KULBICKI ${ }^{10}$, DAVID MOUILLOT ${ }^{3,11}$ and LOÏC PELLISSIER ${ }^{1}$ \\ ${ }^{1}$ Unit of Ecology E Evolution, University of Fribourg, Ch. du Musée 10, CH-1700 Fribourg, Switzerland, ${ }^{2}$ Department of Ecology \\ and Environment, DHI-Group, Hørsholm, Denmark, ${ }^{3}$ Laboratoire Ecologie des Systèmes Marins Côtiers UMR 5119, CNRS, IRD, \\ IFREMER, UM2, UM1, cc 093, Place E. Bataillon, FR-34095 Montpellier Cedex 5, France, ${ }^{4}$ CRIOBE, USR 3278 CNRS-EPHE- \\ UPVD, LABEX 'CORAIL', University of Perpignan, 66860 Perpignan, France, ${ }^{5}$ CESAB-FRB, Immeuble Henri Poincaré, \\ Domaine du Petit Arbois, FR-13857 Aix-en-Provence Cedex 3, France, ${ }^{6}$ EarthByte Group, The University of Sydney, Sydney, \\ NSW, Australia, ${ }^{7}$ Shell International Exploration \& Production, The Hague, The Netherlands, ${ }^{8}$ Center for Ocean and Ice Danish \\ Meteorological Institute, Lyngbyvej 100, 2100 Copenhagen, Denmark, ${ }^{9}$ EPOC, CNRS, Université de Bordeaux, Allée Geoffroy St \\ Hilaire, 33615 Pessac cedex, France, ${ }^{10}$ Laboratoire Arago, UR "CoReUs", Institut pour la Recherche en Développement, Labex \\ Corail, B.P. 44, 66651 Banyuls/mer, France, ${ }^{11}$ Australian Research Council Centre of Excellence for Coral Reef Studies, James Cook \\ University, Townsville, Qld 4811, Australia
}

\begin{abstract}
Coral bleaching events threaten coral reef habitats globally and cause severe declines of local biodiversity and productivity. Related to high sea surface temperatures (SST), bleaching events are expected to increase as a consequence of future global warming. However, response to climate change is still uncertain as future low-latitude climatic conditions have no present-day analogue. Sea surface temperatures during the Eocene epoch were warmer than forecasted changes for the coming century, and distributions of corals during the Eocene may help to inform models forecasting the future of coral reefs. We coupled contemporary and Eocene coral occurrences with information on their respective climatic conditions to model the thermal niche of coral reefs and its potential response to projected climate change. We found that under the RCP8.5 climate change scenario, the global suitability for coral reefs may increase up to $16 \%$ by 2100 , mostly due to improved suitability of higher latitudes. In contrast, in its current range, coral reef suitability may decrease up to $46 \%$ by 2100 . Reduction in thermal suitability will be most severe in biodiversity hotspots, especially in the Indo-Australian Archipelago. Our results suggest that many contemporary hotspots for coral reefs, including those that have been refugia in the past, spatially mismatch with future suitable areas for coral reefs posing challenges to conservation actions under climate change.
\end{abstract}

Keywords: fish, fossil, sea surface temperature, specialists, species distribution model, species richness

\section{Introduction}

Habitats are key for the persistence of biodiversity and productivity but, under climate change, changing environmental conditions may decrease their suitability (Graham et al., 2006; Carnaval et al., 2009; Yannic et al., 2014) imperilling the viability of closely associated species (Bellard et al., 2012; Pellissier et al., 2014). Coral reef habitat is home to over a million species (Knowlton et al., 2010) and provides essential ecosystem services sustaining over 500 million people worldwide (Moberg \& Folke, 1999). Although highly diverse, coral reefs are among the most vulnerable habitats to future climate

Correspondence: Loïc Pellissier, tel. +41 26300 8871, fax +41 26 3009741 ,

e-mail: loic.pellissier@unifr.ch change (Pandolfi et al., 2011) with an increase of only 1$2{ }^{\circ} \mathrm{C}$ in sea surface temperature potentially causing bleaching of coral species (Jones et al., 2004). Mass mortality events related to coral bleaching have recently become a frequent phenomenon and are threatening the integrity of reef habitats and their associated high biodiversity (Jones et al., 2004; Pandolfi et al., 2011). Hence, there is an urgent need to increase our capacity to predict the potential consequences of ongoing climate change on coral reefs to better anticipate potential biodiversity loss (Frieler et al., 2012; Couce et al., 2013; Van Hooidonk et al., 2013).

Coral reefs persist only within relatively narrow ranges of environmental conditions (Kleypas et al., 1999). Corals critically depend on transient relationships with photosynthetic dinoflagellates, but this symbiosis is negatively affected by positive anomalies in 
sea surface temperatures (SST) (Wooldridge, 2013). As most coral reefs reside in temperatures near their upper limits of thermal tolerance (Glynn, 1993; Coles \& Brown, 2003), even a low rise in ocean temperature may result in extensive coral bleaching. Although corals can at times recover from bleaching, frequent or exceptional large-scale events may reduce this capacity leading to a long-term degradation of coral reefs (De'ath et al., 2012). In contrast, improvement of coral growing conditions at higher latitude allows tropical species to expand their distributional range (Vargas-Ángel et al., 2003; Yamano et al., 2011). The ultimate consequence of climate change on worldwide coral reef ecosystem remains uncertain and ranges from optimistic scenarios of adaptation (Hoegh-Guldberg, 2014; Palumbi et al., 2014) to a strong negative effect of climate warming implying coral reef contraction at low latitudes (Hoegh-Guldberg, 1999; Carpenter et al., 2008).

Warming conditions similar to those currently experienced by coral reefs already occurred in the geological past. Therefore, historical reef contraction at low latitudes and their parallel expansion to higher latitudes may have been documented in geological records (Pandolfi \& Kiessling, 2014). Indeed, Kiessling et al. (2012) showed evidence of reef contraction at low latitude during the last interglacial period (around 125 thousand years ago) together with species range shifts to higher latitudes, when ocean temperature was $0.78{ }^{\circ} \mathrm{C}$ warmer than today (McKay et al., 2011; Kiessling et al., 2012). During the Eocene epoch, SST were warmer than today by up to $6{ }^{\circ} \mathrm{C}$ (Hollis et al., 2009; Bijl et al., 2010) and coral reefs were mainly concentrated in mid-latitudes (Flügel \& Kiessling, 2002; Lathuilière \& Marchal, 2009). During this epoch, the highest temperatures occurred in the eastern Tethys around the Indian subcontinent and on the eastern side of Africa, up to Northeast Africa, while the western Tethys and palaeoAtlantic oceans were immersed in relatively cooler waters, as were southern latitudes near Australian continent (Huber \& Caballero, 2011). In the warmest eastern Tethys, the geological record indicates a decline in coral reefs (Scheibner \& Speijer, 2007), while they remained extensive in the western Tethys and palaeoAtlantic oceans (Scheibner \& Speijer, 2008). The response of Tethyan reef systems to the Eocene warm period may provide a potential analogue to ongoing shifts in coral reef ecosystems.

Coral reef decline under climate change may cause extinction cascades given the large number of species that depend on coral habitat (Wilson et al., 2008). Coral growth generates structurally complex reefs that provide habitat to many marine species (Pratchett et al., 2014). In turn, warming and subsequent coral bleaching negatively impacts the structure of coral reef habitats and associated species assemblages (Wilkinson, 1999; Bellwood et al., 2005; Elith et al., 2006; Garpe et al., 2006). In particular, coral reefs support a high diversity of fishes that directly or indirectly depend on corals for their survival (Jones et al., 2004). Loss of live coral decreases habitat structure and complexity inducing a general decline in reef fish diversity and abundance (Jones et al., 2004), this decline being far more severe for highly specialized fishes that live, feed or settle on live corals (Wilson et al., 2006) and imperilling productivity that sustains fisheries (Rogers et al., 2014). A global assessment of the consequence of climate-induced coral reef degradation on fish diversity is thus essential, particularly at low latitude where severe climate warming is expected to threaten biodiversity hotspots.

Models have been developed to investigate the fate of coral reefs under scenarios of climate change using distinct empirical sources (Frieler et al., 2012; Couce et al., 2013; Van Hooidonk et al., 2013). In particular, niche-based models permit mapping of the temperature-driven decline in coral reef suitability (Couce et al., 2013). The main limitation of this approach is that in several regions, the future climates have no presentday analogue, thereby limiting inferences based on comparison with today's occurrences (Guisan \& Thuiller, 2005; Couce et al., 2013). Indeed, using niche-based models to forecast the future distribution of species is relevant only if these models are able to incorporate the complete response curve along wide environmental gradients (Guisan \& Thuiller, 2005). Multi-temporal model calibration may allow calibrating complete response curves and projecting in nonanalogous climates (Nogués-Bravo et al., 2008; Maiorano et al., 2012), but strongly relies on the assumption that fossil records during the past periods reflect environmental limits.

Here, we assess future coral reef suitability loss under climate change using niche-based models that were informed by contemporary and Eocene reef distributions. We calibrated our niche model of coral reefs by combining fossil data during middle Eocene (50-40 Ma) and present-day coral reef occurrences coupled with present and past climatic conditions (Huber \& Caballero, 2011). Palaeo-climate simulations from climate models provide spatially explicit outputs of largescale patterns of temperature for ancient time periods. The result of EOCENE-2240 simulation that was carried out with $2240 \mathrm{ppm}$ of $\mathrm{CO}_{2}$ is a good fit to middle Eocene climate (Eldrett et al., 2009; Huber \& Caballero, 2011). Next, we used our niche-based models to forecast future coral reef thermal suitability and to identify the locations that may be most vulnerable to climate change. Finally, we assessed whether present-day fish diversity hotspots are expected to decrease in suitability for coral reefs in the future using the most compre- 
hensive distribution database of reef-associated fishes (Pellissier et al., 2014).

\section{Materials and methods}

\section{Past, current and future SSTs}

We mapped current and future SSTs using global ocean simulations for the periods 2005-2014, 2050-2060 and 2090-2100. We considered two projections performed using two different state-of-the-art climate models: EC-Earth and IPSL-CM5A-LR, both participating in CMIP5. The version (V2.3) of EC-Earth (Sterl et al., 2012) is a fully coupled atmosphere ocean general circulation model (AOGCM), with oceanic (Nucleus for European Modelling of the Ocean, NEMO), sea-ice (LIM2) and land-surface (HTESSEL) components having been coupled to the IFS atmospheric forecast model through the OASIS3 (Valcke, 2006) coupler. The ocean configuration of NEMO has a resolution of $1^{\circ} \times 1^{\circ}$ with a meridional refinement to $1 / 3^{\circ}$ at the equator, referred to as the ORCA1 grid. Using 42 vertical $z$-layers, vertical ocean resolution increases from $10 \mathrm{~m}$ at the surface to $300 \mathrm{~m}$ at depth and reaches down to $5500 \mathrm{~m}$. The second AOGCM used here is IPSL-CM5A-MR (Dufresne et al., 2013) in its medium-resolution (MR) version as developed for CMIP5. This model is also using NEMO (Madec, 2008) with a resolution of $2^{\circ} \times 2^{\circ}$ with a meridional refinement to $1 / 2^{\circ}$ at the equator, referred to as the ORCA2 grid. It has 31 vertical z-layers and also uses tripolar grid. It is associated with LIM2 sea-ice model (Fichefet \& Maqueda, 1997) and the PISCES module, representing oceanic biogeochemistry (Aumont \& Bopp, 2006), which interacts with the ocean physics and dynamics. The ocean is coupled to LMD5 (Hourdin et al., 2013) atmospheric model with a $144 \times 144 \times$ L39 regular grid associated with land-surface model ORCHIDEE (Krinner et al., 2005). The coupler used is also OASIS3. The IPSL-CM5A-MR AOGCM therefore also provides ocean acidity values that were converted into aragonite saturation state. The models have been forced by the RCP4.5 or RCP8.5 scenarios (RCP stands for representative concentration pathway, the number 4.5 and 8.5 represent the net radiative forcing at the top of the atmosphere due to anthropogenic emissions and land-use changes at the year 2100 in $\mathrm{W} \mathrm{m}^{-2}$, cf. Moss et al., 2010) over the period 2006-2100. We therefore analysed four projections including two different models and two different emission scenarios. For the Eocene, we used the EOCENE2240 simulation with a forcing of $2240 \mathrm{ppm}$ of $\mathrm{CO}_{2}$ (Huber \& Caballero, 2011)

\section{Niche-based modelling}

We coupled current data with data from the middle Eocene rather than early Eocene (that was even warmer) to match with the temporal window of the climatic EOCENE-2240 simulation because fossil records for the early Eocene are too scarce. We collected 204 fossil occurrences of coral reefs from www.paleodb.org for the middle Eocene (50-40 Ma). During that period, coral fossil records were well represented in the western Tethys, eastern Pacific and Atlantic oceans, but in very low frequency in eastern Tethys characterized by high mean annual SST up to $36.7^{\circ} \mathrm{C}$ (Huber \& Caballero, 2011). This is unlikely to result from a lack of sampling effort given the abundant fossil records $(>150)$ of bivalves, gastropods and ostracods from the coast of the subcontinent of India during the same period (www.paleodb.org). Current coral reef geographical locations were obtained from www.reefbase.org and comprised 8789 occurrences.

To model coral reef thermal suitability, we used generalized linear models (GLM, McCullagh \& Nelder, 1989) with a binomial distribution and a logistic link function as implemented in the $\mathrm{R}$ environment ( $\mathrm{R}$ Development Core Team, 2010). This technique avoids over-fitting which is problematic when dealing with palaeo-models (Nogués-Bravo et al., 2008; Svenning et al., 2011). We calibrated the model using both a linear and a quadratic term allowing the fit of a hump-shaped curve with a temperature optimum. We coupled fossil records (i.e. 204 points) with the same number of randomly selected current occurrences. We selected pseudo-absences randomly across the oceans as models based on randomly selected pseudoabsences show higher performance (Wisz \& Guisan, 2009). We randomly selected 204 pseudo-absences coupled with current SST and 204 pseudo-absences coupled with past SST. Averaging several runs with fewer pseudo-absences and equal weighting for presences and absences represents the best approach in regressions and discriminant analyses (BarbetMassin et al., 2012). Therefore, we ran 100 models resampling current presences and pseudo-absences. We considered the average of the estimated parameters for the model projections.

We computed the explained deviance of the modelled response curve. To evaluate the predictive performance of the models, we used five runs of split sample, first calibrating the models on $70 \%$ of the data and validating on the remaining $30 \%$. We measured model performance by true skill statistic, a threshold-dependant evaluator that compares the sensitivity (presences correctly predicted) and specificity (absences correctly predicted) of the model to a hypothetical set of perfect predictions (TSS, Allouche et al., 2006). According to Thuiller et al. (2010), models with TSS $\leq 0.4$ are considered to be poor, whereas those with TSS $>0.4$ are considered to have fair-toexcellent accuracy. We hindcasted the modelled response curve to SST reconstructed for the middle Eocene and forecasted under climate change scenarios. We compared the forecasted coral reef thermal suitability for current period (2005-2014), mid-century (2050-2060) and end of century (2090-2100), respectively, globally and in tropical waters $\left(>25{ }^{\circ} \mathrm{C}\right)$. Thermal suitability for coral reef was combined with bathymetry excluding area with a depth over $75 \mathrm{~m}$ (Kleypas et al., 1999; Pellissier et al., 2014). We computed the shift (positive or negative) in suitability between current and future conditions and the total change in suitability relative to current suitability values. Finally, we compared shift in thermal suitability along latitude to the expected shift in aragonite saturation state, to evaluate the future of coral reefs under both drivers of change. 


\section{Consequences on coral reef biodiversity}

By examining almost 500 references and extracting information from published works, regional checklists, monographs on specific families or genera, and reports (Fig. S1), we obtained information on the presence/absence of 6316 reef fishes in grid cells of $5^{\circ} \times 5^{\circ}$, corresponding to approximately $555 \times 555 \mathrm{~km}$ at the equator (Parravicini et al., 2013; Pellissier et al., 2014). In addition, we used the distribution maps of 838 coral species (IUCN, 2014) to extract the species composition for each grid cell of $5^{\circ} \times 5^{\circ}$. We tested the relationship between shift in thermal suitability (current 2005-2014 compared to end of the century 2090-2100) and the coral and reef fish species richness using GLM with a quasi-Poisson distribution. We fitted models including both linear and quadratic terms.

Finally, we assessed whether some fish categories may face larger decrease in suitability. Each fish species was classified into categories according to the following specializations: coral feeders, species associated with coral reef habitat and species with specific biotic interactions (urchins, anemones, seagrasses, etc.). For each species, we computed the mean shift in suitability for coral reef over the occupied cells. We tested the relationship between species range shift in suitability and fish trait categories using a linear model associated with an F-test.

\section{Results}

\section{Model validation and response curves}

The GLM response curve showed a hump-shaped relationship between SST and suitability for coral reefs (Fig. 1). Considering a quadratic term in the model allowed a better fit ( $\mathrm{AIC}_{\text {mean }}$ averaged across the 100 runs $=635.4) \quad$ compared to linear term only $\left(\mathrm{AIC}_{\text {mean }}=767.6\right)$ indicating a temperature optimum

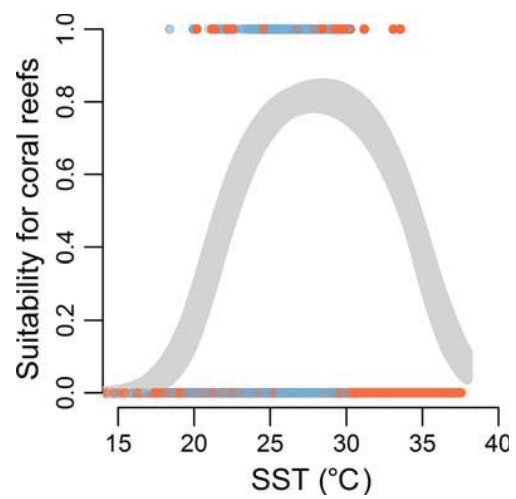

Fig. 1 Thermal response curve of the generalized linear models (GLM) relating both current geographical location and fossil occurrences to yearly average sea surface temperature for the current and Eocene periods, respectively. The range of grey values represents the variability related to the selection of presence and pseudo-absence. Blue points represent current presences and pseudo-absences, while red points represent past data used to calibrate the models. for coral reefs. The explained deviance was higher $\left(D_{\text {mean }}=0.41\right)$ for the model including both linear and quadratic terms than for the model with only a linear term $\left(D_{\text {mean }}=0.25\right)$. Our results showed credible predictive power, when validated on both current geographical locations $(\mathrm{TSS}=0.81$ ) and fossil occurrences $(\mathrm{TSS}=0.74)$.

\section{Projections under climate change scenarios}

According to the hindcasted model to reconstructed Eocene climatic conditions, high thermal suitability for coral reefs extended up to $50^{\circ}$ of latitude, but suitability was low along the coasts of the subcontinent of India from the north-eastern side of Africa (Fig. S2). The hindcasted model also indicated that coral reef suitability during the middle to late Eocene was highest in the west Tethys Sea as well as along a latitudinal belt from Madagascar to Palaeo-Australia (Fig. S2).

Comparing the current and future thermal suitability for the RCP8.5 scenario, we found that the total suitability of coral reefs may globally increase up to $16 \%$ using EC-Earth RCP8.5 scenario, following an increase in thermal suitability for coral reefs at high latitudes. In contrast, using the IPSL-CM5A-MR RCP8.5 scenario, total suitability shows a more balanced trend between increase and decrease for the period 2090-2100, given a more pronounced decrease in thermal suitability at low latitude (Table 1).

When considering only the surface currently occupied by coral reefs (i.e. area with SST $>25{ }^{\circ} \mathrm{C}$, Kleypas et al., 1999) at lower latitudes, current total suitability would decrease by $32 \%$ using the EC-Earth RCP8.5 scenario and by $46 \%$ using the IPSL-CM5A-MR RCP8.5 scenario for the period 2091-2100 (Table 1). In the most sensitive cells, future suitability is forecasted to decrease by up to 0.47 using the EC-Earth RCP8.5 scenario and 0.44 using the IPSL-CM5A-MR RCP8.5 scenario compared to current suitability for coral reefs in those cells (Table 1). The most impacted areas according to both the EC-Earth and the IPSL-CM5A-MR RCP8.5 scenarios correspond to the tropical Indo-Pacific Ocean. While thermal suitability is forecasted to increase at high latitudes, the IPSL-CM5A-MR coupler forecasted an average decrease in aragonite saturation state of 1.2 unit change across all latitude (Fig. 3).

\section{Consequences on coral reef biodiversity}

Coral and fish diversity hotspots are generally associated with a negative shift in coral reef thermal suitability. We found a negative relationship between the total fish species richness and the shift in suitability between current and future climatic conditions under the 
Table 1 Suitability for coral reefs across the globe

\begin{tabular}{lcclll}
\hline & \multicolumn{2}{l}{$\begin{array}{l}\text { Total suitability } \\
\text { change (\%) }\end{array}$} & & $\begin{array}{l}\text { Max. } \\
\text { increase }\end{array}$ & $\begin{array}{l}\text { Max. } \\
\text { decrease }\end{array}$ \\
\cline { 2 - 3 } & Global & $>25{ }^{\circ} \mathrm{C}$ & & \\
& 4.02 & -13.44 & 0.23 & -0.12 \\
EC 4.5 2050 & 9.14 & -22.88 & 0.33 & -0.18 \\
EC 4.5 2100 & 8.67 & -27.64 & 0.28 & -0.24 \\
EC 8.5 2050 & 16.00 & -31.81 & 0.42 & -0.47 \\
EC 8.5 2100 & -3.98 & -37.23 & 0.49 & -0.23 \\
IPSL 4.5 2050 & -2.40 & -38.39 & 0.52 & -0.22 \\
IPSL 4.5 2100 & -1.83 & -38.39 & 0.52 & -0.21 \\
IPSL 8.5 2050 & -0.00 & -46.28 & 0.66 & -0.44 \\
IPSL 8.5 2100 & 0.06 &
\end{tabular}

Total suitability provides the percentage increase or decrease in the sum of cell suitabilities globally or in currently occupied areas (sea surface temperature $>25^{\circ} \mathrm{C}$ ). The maximum increase and decrease columns indicate the extremes of suitability increase or decrease in individual cells across the globe for the two AOGCMs EC-Earth (EC) and IPSL-CM5A-MR (IPSL) and two climate change scenarios (RCP4.5 and RCP8.5).
RCP8.5 scenario (Table 1; Fig. 4), both using the EC-Earth RCP8.5 scenario $\left(R^{2}=0.34\right.$, linear $t=-8.8$, $P<0.0001$, quadratic $t=1.9, P=0.04)$ and the IPSLCM5A-MR RCP8.5 scenario $\left(R^{2}=0.38\right.$, linear $t=-10.8$, $P<0.0001$, quadratic $t=0.01, P=0.5)$. A similar negative relationship exists between coral species richness and the shift in suitability, both using the EC-Earth RCP8.5 scenario $\left(R^{2}=0.29\right.$, linear $t=-7.6, P<0.0001$, quadratic $t=1.4, P=0.17)$ and the IPSL-CM5A-MR RCP8.5 scenario $\left(R^{2}=0.34\right.$, linear $t=-10.0, P<0.0001$, quadratic $t=-0.5, P=0.6)$. The Indo-Pacific Ocean is richer than the Atlantic for both coral and fish taxa and is expected to undergo a higher loss in thermal suitability for coral reefs (Fig. S1; Fig. 2).

Considering fish categories, we found that species feeding on corals or with dependency on coral reef habitat are associated with areas with slightly stronger decrease in suitability compared to species having other types of biotic interactions or no interaction with coral reefs (Fig. 4). This result was consistent under both the EC-Earth $\left(R^{2}=0.07, F=73.1, P<0.0001\right)$ and
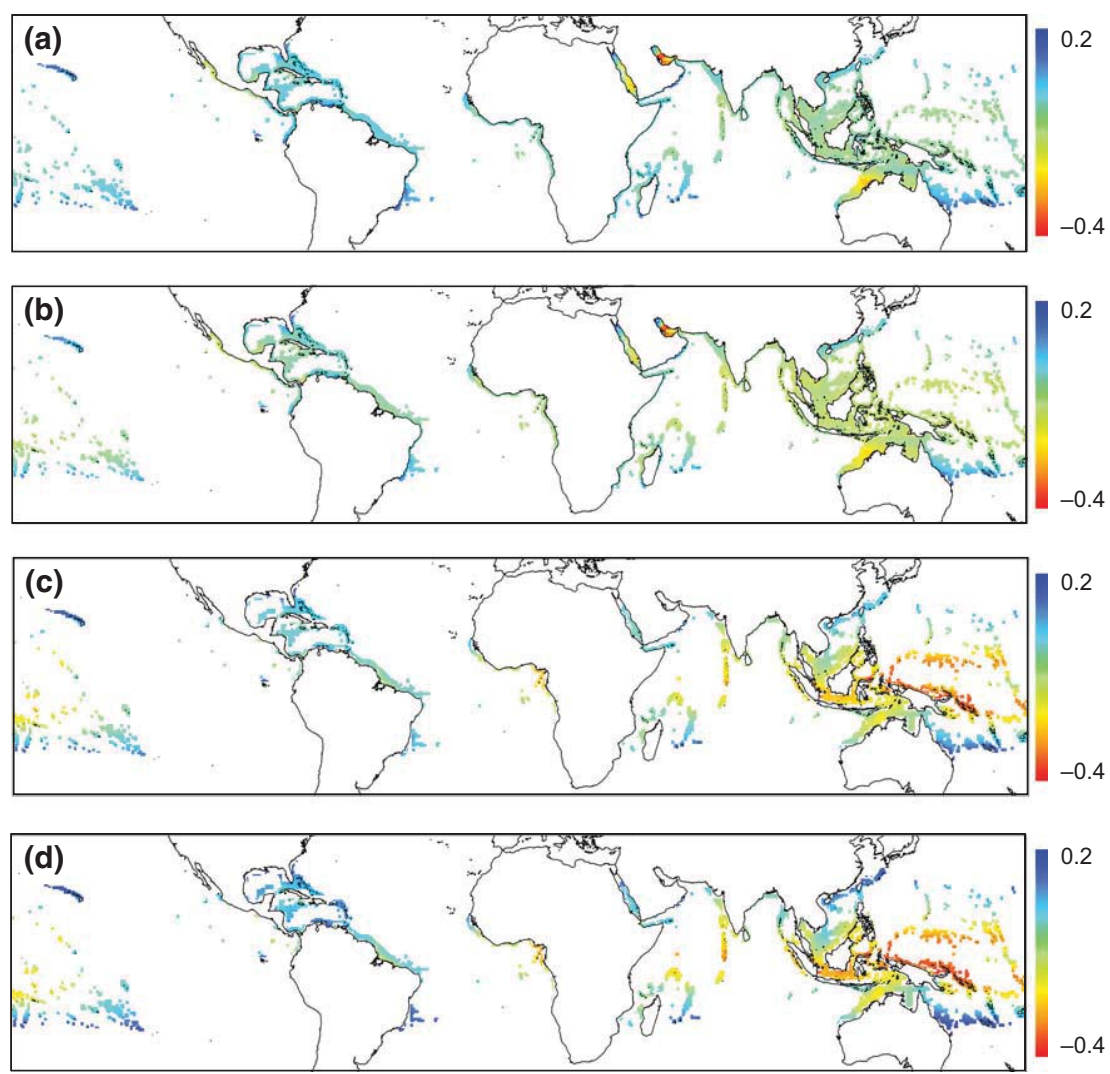

Fig. 2 Differences between current and projected future thermal suitability for coral reefs for areas with current sea surface temperatures (SST) $>25{ }^{\circ} \mathrm{C}$ in the globe oceans. A decrease in suitability indicates a decrease in the likelihood of coral reef persistence. Shown are the projected shifts for (a) mid-century (2051-2060) and (b) end of century (2091-2100) for AOGCM EC-Earth RCP8.5 scenario, and in the same in c) and d) for ISPL RCP8.5 scenario. Orange-red areas indicate areas that are expected to show a decrease in thermal suitability, while blue areas indicate an increase in suitability for coral reefs. 
the IPSL-CM5A-MR RCP8.5 scenarios $\left(R^{2}=0.08\right.$, $F=82.9, P<0.0001)$. However, the explained deviance of the relationship was low, thus limiting confident forecasts based on fish categories.

\section{Discussion}

There is growing concern that the increase in frequency and severity of mass bleaching events may lead to major losses of coral reef habitat and their associated biodiversity in the near future (Hughes et al., 2003; Baker et al., 2008; Van Hooidonk et al., 2013). So far, future projections of coral reefs suitability were limited by the lack of climate analogues to those expected for the near future (Couce et al., 2013). Here, we overcome this limitation by combining current coral reef occurrences with fossil records from the Eocene, thereby modelling the full response curve of coral reef suitability (Fig. 1). Future projections of the modelled response curve indicate that the most marked decrease in coral reef thermal suitability will involve the most speciesrich areas for both coral and fish species. As persistent coral reef habitat is essential to preserve marine biodiversity (Pellissier et al., 2014; Rogers et al., 2014), a decreasing suitability in biodiversity hotspots will pose new challenges to conservation actions including the design of reserve networks or the focus on the most vulnerable lineages or life-history traits (Mumby et al., 2011; Andrello et al., 2014).

Tropical coral reefs have been hypothesized to occur very close to their upper tolerance threshold for temperature (Hallock et al., 2006), and our response curve of the model confirmed this. Our records from the Eocene and contemporary times confirm that the thermal suitability for coral reefs strongly decreases in SST conditions warmer than approximately $32{ }^{\circ} \mathrm{C}$ (Fig. 1). This threshold corresponds to the responses of individual species observed in laboratory experiments (Glynn \& D'Croz, 1990; Iglesias-Prieto et al., 1992; Randall \& Szmant, 2009). For instance, Iglesias-Prieto et al.(1992) showed how Symbiodinium photosynthesis decreases above a temperature of $30{ }^{\circ} \mathrm{C}$ and ceases completely at $34-36{ }^{\circ} \mathrm{C}$. Many other species show reduced survivorship beyond a temperature of $32{ }^{\circ} \mathrm{C}$, but some show a higher tolerance. For instance, northern Red Sea corals species are able to tolerate temperature up to $34^{\circ} \mathrm{C}$ (Fine et al., 2013), but these warm areas are characterized by lower densities of zooxanthellae (Fine et al., 2013). Transplantation experiments have shown that a coral species (Acropora hyacinthus) can acclimatize to temperatures as high as $34{ }^{\circ} \mathrm{C}$ within a 2-year period suggesting potential for adaptation to warmer temperature (Palumbi et al., 2014). So far, extreme SST anomalies remain episodic events, but according to the
IPSL-CM5A-MR RCP8.5 scenario, the annual mean temperature may reach $34.7^{\circ} \mathrm{C}$ by 2100 in the IndoPacific Ocean, implying a durable stress on coral reefs in tropical regions. Our forecasted coral reef suitability loss in tropical waters corroborates monitoring studies which indicate increase by $30 \%$ of coral mortality rates since the 1980s (Donner et al., 2005). The growth of Porites spp. on the Great Barrier Reef decreased in calcification rate by $21 \%$ between 1988 and 2003 (Cooper et al., 2008), while analyses of the reef-forming coral Diploastrea heliopora in the Red Sea revealed a decrease by $30 \%$ of growth since 1998 (Cantin et al., 2010). In turn, coral reef may retract from lower latitude, possibly replaced by other forms of reefs (Bell et al., 2013).

With their biological and structural complexity, coral reefs support the world's greatest diversity of marine fishes and biomass productivity each year (Price et al., 2011; Parravicini et al., 2013; Pellissier et al., 2014; Rogers et al., 2014). Current hotspots of fish and coral diversity occur in the regions with the warmest SST such as the Indo-Australian Archipelago, the Maldives or the Red Sea because those regions served as refugia during cold periods of the Quaternary (Pellissier et al., 2014). However, those regions will also be the first to show a reduction in habitat suitability under warmer climate (Fig. 2). Moreover, our results indicate that species specialized on coral reefs are disproportionally distributed in regions with high decrease in suitability (Fig. 4). Our results have therefore strong implications for the conservation of marine tropical biodiversity hotspots that provide essential food provision as they are found to be more prone to a loss of coral reef thermal suitability under climate change.

The net effect of climate change on coral reefs thermal suitability will be positive at higher latitudes. Colonization of higher latitudes by reef-forming coral species is already underway as seen in Japan (Yamano et al., 2011) and Florida (Vargas-Ángel et al., 2003). However, while thermal condition for coral growth will increase at higher latitude, the aragonite saturation state will decrease across all latitudes and this may slow coral colonization of high-latitude reefs (Fig. 3, Van Hooidonk et al., 2013). The main uncertainties for fish biodiversity are the amount of time required for coral reef habitats to form at higher latitudes and whether species in current hotspots will be able to disperse to these new habitats in time to escape extinction as habitats at lower latitudes become lost. Mora et al. (2012) suggested that dispersal is probably not a major concern for most fish species to reach newly available area; however, species with especially short larval stage may find dispersal to new distant habitats to be a challenge (Luiz et al., 2013). The low fish species diversity encountered in many suitable reef habitats at low lati- 

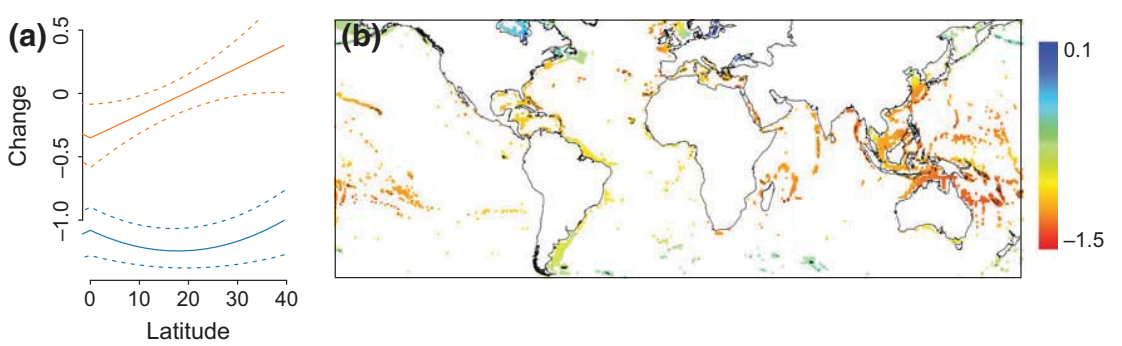

Fig. 3 (a) Relationship between shift thermal suitability for coral reefs (in orange), shift in aragonite saturation state (in blue) and latitude (degree) for ISPL RCP8.5 scenario for the period 2050-2100. The dashed lines represent quantile regression on the 5th and 95th percentile. (b) Global map of shift in aragonite saturation state for ISPL RCP8.5 scenario showing a decrease across all latitude with the exception of colder waters at highest latitudes.

(a)

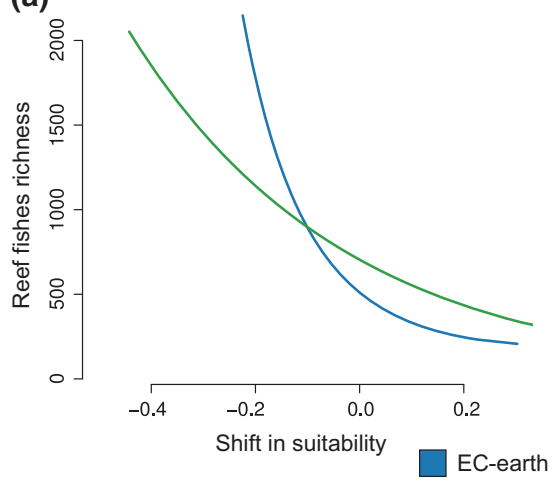

(b)

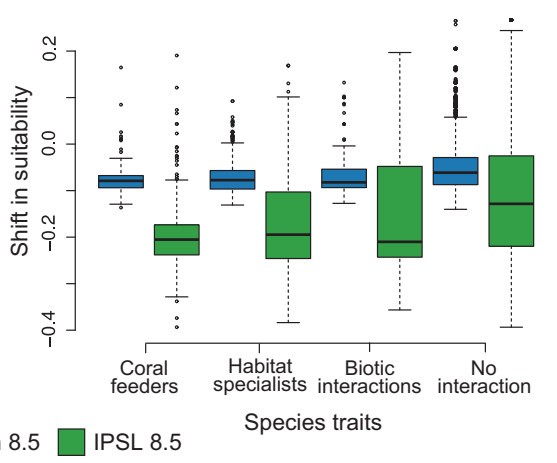

Fig. 4 (a) Relationships between the shift in suitability between current (2005-2014) and future (2090-2100) sea surface temperature and the reef fishes richness under EC-Earth RCP8.5 (blue) and IPSL-CM5A-MR RCP8.5 scenarios (green). (b) Boxplots of the mean shift in suitability across the range of 6316 species classified according to their specialization, in particular, being coral feeders, coral habitat specialist, showing biotic interactions with species occupying the reef or no interaction. Results for EC-Earth RCP8.5 scenario is shown in blue and IPSL-CM5A-MR RCP8.5 scenario in green.

tudes may be explained by limited dispersal capacity and high habitat specialization that limited recolonization rates since the last glacial maximum (Pellissier et al., 2014). It is therefore unlikely that specialized species can disperse in a manner to keep pace with ongoing climate change. Human-mediated transport via ballast water may help species colonize distant suitable habitat. Assisted transplantation of coral reefs in suitable regions under climate change might also be an alternative to preserve coral reef biodiversity under climate change (Coles \& Riegl, 2013).

As any study that relies on fossil data (Nogués-Bravo et al., 2008; Lorenzen et al., 2011), our results are based on the assumption that the fossil sample is representative of a taxon's environmental range limit. Our study assumes that the absence of fossils of coral reefs in the eastern Tethys Sea during the Eocene was caused by unsuitable thermal conditions. Fossils of other marine organisms in eastern Tethys Sea seem to discount possible sampling effect, but it is possible that the fossil record under-represents past coral distribution. In addition, we assumed that the low frequency of coral reef fossils in the eastern Tethys Sea was the result of high SST, but other associated factors such as increased or decreased salinity, sea-level rise (Speijer \& Morsi, 2002) or ocean acidifications (Zachos et al., 2005; Gibbs et al., 2010) and other geochemical changes (Cohen et al., 2007) during the Eocene might also have impacted coral reefs. Similarly, when projecting reef suitability under climate change scenarios, we only considered SST, while ongoing ocean acidification across latitudes is also a major concern for the future of coral reefs (Hoegh-Guldberg et al., 2007). Finally, here we modelled coral reef suitably along a gradient of yearly average SST, while extremes of high temperature during events such as ENSO may increase the pace of coral degradation (Toth et al., 2012).

Overall, our results forecast locations of expansion of coral reef habitat and potential range reduction under warmer climate. Our model coupling both current coral reef occurrences and fossil records suggests that the projected rise of SST may cause retraction of coral reefs from 
low latitudes, with dire consequences on biodiversity associated with this habitat. If this happens, these coral reef ecosystems may shift towards systems that are dominated by other organisms such as sponges, cyanobacteria and algae (Bell et al., 2013), hence reducing the current services that these ecosystems currently provide (e.g. tourism and fisheries) with up to threefold fish productivity loss (Rogers et al., 2014). Even if temperatures at higher latitudes become more favourable in the future, given that ocean acidification remains limited, coral reef formation will take time and only the most vagile fish species will be likely to colonize over such great distances. As for higher latitudes, locations with intermediate water depths areas may offer cooler water temperature and could act as refuge area for coral reefs (Riegl \& Piller, 2003; Lesser et al., 2009). Further study should investigate the role of depth refugia and other micro-refugia in preserving coral reef biodiversity.

\section{Acknowledgements}

This work was supported by a the Danish FNU grant no. 12-126430, the 'Félix Bonjour' grant from the Société Académique Vaudoise and the FRB CESAB-GASPAR project. $\mathrm{CH}$ was supported by ARC Linkage LP0989312. Lune Gene Yeo is thanked for reverse-engineering the Smith palaeo-geographical data. We thank the three anonymous reviewers who provided important advices to improve the manuscript.

\section{References}

Allouche O, Tsoar A, Kadmon R (2006) Assessing the accuracy of species distribution models: Prevalence, kappa and the true skill statistic (TSS). Journal of Applied Ecology, 43, 1223-1232.

Andrello M, Jacobi MN, Manel S, Thuiller W, Mouillot D (2014) Extending networks of protected areas to optimize connectivity and population growth rate. Ecography, 37, 1-10.

Aumont O, Bopp L (2006) Globalizing results from ocean in situ iron fertilization studies. Global Biogeochemical Cycles, 20, GB2017.

Baker AC, Glynn PW, Riegl B (2008) Climate change and coral reef bleaching: an ecological assessment of long-term impacts, recovery trends and future outlook. Estuarine, Coastal and Shelf Science, 80, 435-471.

Barbet-Massin M, Jiguet F, Albert CH, Thuiller W (2012) Selecting pseudo-absences for species distribution models: how, where and how many? Methods in Ecology and Evolution, 3, 327-338.

Bell JJ, Davy SK, Jones T, Taylor MW, Webster NS (2013) Could some coral reefs become sponge reefs as our climate changes? Global Change Biology, 19, 2613-2624.

Bellard C, Bertelsmeier C, Leadley P, Thuiller W, Courchamp F (2012) Impacts of climate change on the future of biodiversity. Ecology Letters, 15, 365-377.

Bellwood DR, Hughes TP, Connolly SR, Tanner J (2005) Environmental and geometric constraints on Indo-Pacific coral reef biodiversity. Ecology Letters, 8, 643-651.

Bijl PK, Houben AJP, Schouten S et al. (2010) Transient middle Eocene atmospheric $\mathrm{CO}_{2}$ and temperature variations. Science, 330, 819-821.

Cantin NE, Cohen AL, Karnauskas KB, Tarrant AM, McCorkle DC (2010) Ocean warming slows coral growth in the Central Red Sea. Science, 329, 322-325.

Carnaval AC, Hickerson MJ, Haddad CFB, Rodrigues MT, Moritz C (2009) Stability predicts genetic diversity in the Brazilian Atlantic forest hotspot. Science, 323, 785-789.

Carpenter KE, Abrar M, Aeby G et al. (2008) One-third of reef-building corals face elevated extinction risk from climate change and local impacts. Science, 321, 560-563.

Cohen AS, Coe AL, Kemp DB (2007) The Late Palaeocene-Early Eocene and Toarcian (Early Jurassic) carbon isotope excursions: a comparison of their time scales, asso- ciated environmental changes, causes and consequences. Journal of the Geological Society, 164, 1093-1108.

Coles SL, Brown BE (2003) Coral bleaching - capacity for acclimatization and adaptation. Advances in Marine Biology, 46, 183-223.

Coles SL, Riegl BM (2013) Thermal tolerances of reef corals in the Gulf: a review of the potential for increasing coral survival and adaptation to climate change through assisted translocation. Marine Pollution Bulletin, 72, 323-332.

Cooper TF, De'Ath G, Fabricius KE, Lough JM (2008) Declining coral calcification in massive Porites in two nearshore regions of the northern Great Barrier Reef. Global Change Biology, 14, 529-538.

Couce E, Ridgwell A, Hendy EJ (2013) Future habitat suitability for coral reef ecosystems under global warming and ocean acidification. Global Change Biology, 19, 3592-3606.

De'ath G, Fabricius KE, Sweatman H, Puotinen M (2012) The 27-year decline of coral cover on the Great Barrier Reef and its causes. Proceedings of the National Academy of Sciences of the United States of America, 109, 17995-17999.

Donner SD, Skirving WJ, Little CM, Oppenheimer M, Hoegh-Guldberg O (2005) Global assessment of coral bleaching and required rates of adaptation under climate change. Global Change Biology, 11, 2251-2265.

Dufresne J-L, Foujols M-A, Denvil S et al. (2013) Climate change projections using the IPSL-CM5 Earth System Model: from CMIP3 to CMIP5. Climate Dynamics, 40, 2123-2165.

Eldrett JS, Greenwood DR, Harding IC, Huber M (2009) Increased seasonality through the Eocene to Oligocene transition in northern high latitudes. Nature, 459, 969-973.

Elith J, Graham CH, Anderson RP et al. (2006) Novel methods improve prediction of species' distributions from occurrence data. Ecography, 29, 129-151.

Fichefet T, Maqueda M (1997) Sensitivity of a global sea ice model to the treatment of ice thermodynamics and dynamics. Journal of Geophysical Research: Oceans, 102, 2609-2612.

Fine M, Gildor H, Genin A (2013) A coral reef refuge in the Red Sea. Global Change Biology, 19, 3640-3647

Flügel E, Kiessling W (2002) Patterns of Phanerozoic reef crises. Phanerozoic Reef Patterns, 72, 691-733.

Frieler K, Meinshausen M, Golly A, Mengel M, Lebek K, Donner SD, Hoegh-Guldberg $\mathrm{O}$ (2012) Limiting global warming to $2{ }^{\circ} \mathrm{C}$ is unlikely to save most coral reefs. Nature Climate Change, 3, 165-170.

Garpe KC, Yahya SAS, Lindahl U, Öhman MC (2006) Long-term effects of the 1998 coral bleaching event on reef fish assemblages. Marine Ecology Progress Series, 315, 237-247.

Gibbs SJ, Stoll HM, Bown PR, Bralower TJ (2010) Ocean acidification and surface water carbonate production across the Paleocene-Eocene thermal maximum. Earth and Planetary Science Letters, 295, 583-592.

Glynn PW (1993) Coral reef bleaching: ecological perspectives. Coral Reefs, 12, 1-17.

Glynn PW, D'Croz L (1990) Experimental evidence for high temperature stress as the cause of El Niño-coincident coral mortality. Coral Reefs, 8, 181-191.

Graham CH, Moritz C, Williams SE (2006) Habitat history improves prediction of biodiversity in rainforest fauna. Proceedings of the National Academy of Sciences of the United States of America, 103, 632-636.

Guisan A, Thuiller W (2005) Predicting species distribution: offering more than simple habitat models. Ecology Letters, 8, 993-1009.

Hallock P, Williams DE, Fisher EM, Toler SK (2006) Bleaching in foraminifera with algal symbionts: implications for reef monitoring and risk assessment. Anuário do Instituto de Geociências, 29, 108-128.

Hoegh-Guldberg O (1999) Climate change, coral bleaching and the future of the world's coral reefs. Marine and Freshwater Research, 50, 839-866.

Hoegh-Guldberg O (2014) Coral reef sustainability through adaptation: glimmer of hope or persistent mirage? Current Opinion in Environmental Sustainability, 7, 127-133.

Hoegh-Guldberg O, Mumby PJ, Hooten AJ et al. (2007) Coral reefs under rapid climate change and ocean acidification. Science, 318, 1737-1742.

Hollis CJ, Handley L, Crouch EM et al. (2009) Tropical sea temperatures in the highlatitude South Pacific during the Eocene. Geology, 37, 99-102.

Hourdin F, Foujols M-A, Codron F et al. (2013) Impact of the LMDZ atmospheric grid configuration on the climate and sensitivity of the IPSL-CM5A coupled model. Climate Dynamics, 40, 2167-2192.

Huber M, Caballero R (2011) The early Eocene equable climate problem revisited. Climate of the Past, 7, 603-633.

Hughes TP, Baird AH, Bellwood DR et al. (2003) Climate change, human impacts, and the resilience of coral reefs. Science, 301, 929-933.

Iglesias-Prieto R, Matta JL, Robins WA, Trench RK (1992) Photosynthetic response to elevated temperature in the symbiotic dinoflagellate Symbiodinium microadriaticum 
in culture. Proceedings of the National Academy of Sciences of the United States of America, 89, 10302-10305.

IUCN (2014) The IUCN Red List of Threatened Species. Version 2014.3. Available from: www.iucnredlist.org (accessed October 25 2014).

Jones GP, McCormick MI, Srinivasan M, Eagle JV (2004) Coral decline threatens fish biodiversity in marine reserves. Proceedings of the National Academy of Sciences of the United States of America, 101, 8251-8253.

Kiessling W, Simpson C, Beck B, Mewis H, Pandolfi JM (2012) Equatorial decline of reef corals during the last Pleistocene interglacial. Proceedings of the National Academy of Sciences of the United States of America, 109, 21378-21383.

Kleypas JA, McManus JW, Meñez LAB (1999) Environmental limits to coral reef development: where do we draw. American Zoologist, 39, 146-159.

Knowlton N, Brainard RE, Fischer R, Moews M, Plaisance L, Caley MJ (2010) Coral reef biodiversity. In: Life in the World's Oceans: Diversity, Distribution, and Abundance (ed. McIntyre AD), pp. 65-74. Wiley-Blackwell, Oxford, UK.

Krinner G, Viovy N, de Noblet-Ducoudré N et al. (2005) A dynamic global vegetation model for studies of the coupled atmosphere-biosphere system. Global Biogeochemical Cycles, 19, GB1015.

Lathuilière B, Marchal D (2009) Extinction, survival and recovery of corals from the Triassic to Middle Jurassic time. Terra Nova, 21, 57-66.

Lesser MP, Slattery M, Leichter JJ (2009) Ecology of mesophotic coral reefs. Journal of Experimental Marine Biology and Ecology, 375, 1-8.

Lorenzen ED, Nogués-Bravo D, Orlando L et al. (2011) Species-specific responses of Late Quaternary megafauna to climate and humans. Nature, 479, 359-364.

Luiz OJ, Allen AP, Robertson DR et al. (2013) Adult and larval traits as determinants of geographic range size among tropical reef fishes. Proceedings of the National Academy of Sciences of the United States of America, 41, 16498-16502.

Madec G (2008) NEMO ocean engine. Note du Pôle de modélisation 27. Institut PierreSimon Laplace (IPSL), Paris.

Maiorano L, Cheddadi R, Zimmermann NE et al. (2012) Building the niche through time: using 13,000 years of data to predict the effects of climate change on three tree species in Europe. Global Ecology and Biogeography, 22, 302-317.

McCullagh P, Nelder JA (1989) Generalized Linear Models, 2nd edn. Chapman and Hall, London.

McKay NP, Overpeck JT, Otto-Bliesner BL (2011) The role of ocean thermal expansion in Last Interglacial sea level rise. Geophysical Research Letters, 38, L14605.

Moberg F, Folke C (1999) Ecological goods and services of coral reef ecosystems. Ecological Economics, 29, 215-233.

Mora C, Treml EA, Roberts J, Crosby K, Roy D, Tittensor DP (2012) High connectivity among habitats precludes the relationship between dispersal and range size in tropical reef fishes. Ecography, 35, 89-96.

Moss RH, Edmonds JA, Hibbard KA et al. (2010) The next generation of scenarios for climate change research and assessment. Nature, 463, 747-756.

Mumby PJ, Elliott IA, Eakin CM et al. (2011) Reserve design for uncertain responses of coral reefs to climate change. Ecology Letters, 14, 132-140.

Nogués-Bravo D, Rodríguez J, Hortal J, Batra P, Araújo MB (2008) Climate change, humans, and the extinction of the woolly mammoth. PLoS Biology, 6, 685-692.

Palumbi SR, Barshis DJ, Traylor-Knowles N, Bay RA (2014) Mechanisms of reef coral resistance to future climate change. Science, 344, 895-898.

Pandolfi JM, Kiessling W (2014) Gaining insights from past reefs to inform understanding of coral reef response to global climate change. Current Opinion in Environmental Sustainability, 7, 52-58.

Pandolfi JM, Connolly SR, Marshall DJ, Cohen AL (2011) Projecting coral reef futures under global warming and ocean acidification. Science, 333, $418-422$.

Parravicini V, Kulbicki M, Bellwood DR et al. (2013) Global patterns and predictors of tropical reef fish species richness. Ecography, 36, 1254-1262.

Pellissier L, Leprieur F, Parravicini V et al. (2014) Quaternary coral reef refugia preserved fish diversity. Science, 344, 1016-1019.

Pratchett MS, Hoey AS, Wilson SK (2014) Reef degradation and the loss of critical ecosystem goods and services provided by coral reef fishes. Current Opinion in Environmental Sustainability, 7, 37-43.

Price SA, Holzman R, Near TJ, Wainwright PC (2011) Coral reefs promote the evolution of morphological diversity and ecological novelty in labrid fishes. Ecology Letters, 14, 462-469.

R Development Core Team (2010) R: A language and environment for statistical computing. R Foundation for Statistical Computing, Vienna, Austria. Available at: http://www.R-project.org (accessed October 25 2014).

Randall CJ, Szmant AM (2009) Elevated temperature reduces survivorship and settlement of the larvae of the Caribbean scleractinian coral, Favia fragum (Esper). Coral Reefs, 28, 537-545.
Riegl B, Piller WE (2003) Possible refugia for reefs in times of environmental stress. International Journal of Earth Sciences, 92, 520-531.

Rogers A, Blanchard JL, Mumby PJ (2014) Vulnerability of coral reef fisheries to a loss of structural complexity. Current Biology, 24, 1000-1005.

Scheibner C, Speijer RP (2007) Decline of coral reefs during late Paleocene to early Eocene global warming. eEarth Discussions, 2, 133-150.

Scheibner C, Speijer RP (2008) Late Paleocene-early Eocene Tethyan carbonate platform evolution - A response to long- and short-term paleoclimatic change. EarthScience Reviews, 90, 71-102.

Speijer RP, Morsi AMM (2002) Ostracode turnover and sea-level changes associated with the Paleocene-Eocene thermal maximum. Geology, 30, 23-26.

Sterl A, Bintanja R, Brodeau L et al. (2012) A look at the ocean in the EC-Earth climate model. Climate Dynamics, 39, 2631-2657.

Svenning J-C, Fløjgaard C, Marske KA, Nógues-Bravo D, Normand S (2011) Applications of species distribution modeling to paleobiology. Quaternary Science Reviews, 30, 2930-2947.

Thuiller W, Lafourcade B, Araujo M (2010) Presentation Manual for BIOMOD. Laboratoire d'écologie Alpine, University Joseph Fourier, Grenoble.

Toth LT, Aronson RB, Vollmer SV et al. (2012) ENSO Drove 2500-year Collapse of Eastern Pacific Coral Reefs. Science, 337, 81-84.

Valcke S (2006) OASIS3 user guide (prism_2-5). PRISM Support Initiative Report, 3, 64 .

Van Hooidonk R, Maynard JA, Planes S (2013) Temporary refugia for coral reefs in a warming world. Nature Climate Change, 3, 508-511.

Vargas-Ángel B, Thomas JD, Hoke SM (2003) High-latitude Acropora cervicornis thickets off Fort Lauderdale, Florida, USA. Coral Reefs, 22, 465-473.

Wilkinson CR (1999) Global and local threats to coral reef functioning and existence: review and predictions. Marine and Freshwater Research, 50, 867-878.

Wilson SK, Graham NAJ, Pratchett MS, Jones GP, Polunin NVC (2006) Multiple disturbances and the global degradation of coral reefs: are reef fishes at risk or resilient? Global Change Biology, 12, 2220-2234.

Wilson SK, Burgess SC, Cheal AJ et al. (2008) Habitat utilization by coral reef fish: implications for specialists vs. generalists in a changing environment. Journal of Animal Ecology, 77, 220-228.

Wisz MS, Guisan A (2009) Do pseudo-absence selection strategies influence species distribution models and their predictions? An information-theoretic approach based on simulated data. BMC Ecology, 9, 8 .

Wooldridge SA (2013) Breakdown of the coral-algae symbiosis: towards formalising a linkage between warm-water bleaching thresholds and the growth rate of the intracellular zooxanthellae. Biogeosciences, 10, 1647-1658.

Yamano H, Sugihara K, Nomura K (2011) Rapid poleward range expansion of tropical reef corals in response to rising sea surface temperatures. Geophysical Research Letters, 38, L04601.

Yannic G, Pellissier L, Ortego J et al. (2014) Genetic diversity in caribou linked to past and future climate change. Nature Climate Change, 4, 132-137.

Zachos JC, Röhl U, Schellenberg SA et al. (2005) Rapid acidification of the ocean during the Paleocene-Eocene thermal maximum. Science, 308, 1611-1615.

\section{Supporting Information}

Additional Supporting Information may be found in the online version of this article:

Figure S1. Species richness maps for (a) coral species and (b) reef fish species.

Figure S2.Mid-Eocene reconstruction of suitability for coral reefs using reconstructed absolute continental positions.

Figure S3. Response curve of the model in relation to sea surface temperature when calibrated on current species occurrences and temperatures.

Figure S4. Forecasted coral reef suitability for the period 2090-2100 under EC-Earth RCP8.5 and ISPL RCP8.5 scenarios 